\title{
CRIMINALIZING "PRO-IMMIGRANT" INITIATIVES: REDUCING THE SPACE OF HUMAN ACTION
}

\author{
Vlasta JALUŠıČ
}

COBISS 1.01

\section{ABSTRACT \\ Criminalizing "Pro-Immigrant" Initiatives: Reducing the Space of Human Action}

The article addresses the problem of the surveillance, disciplining and criminalization of practices of non-governmental initiatives which offer help to irregular migrants, asylum seekers and refugees in Slovenia and four neighbouring countries. Based on original empirical work - interviews with members of NGOs - it analyses the dynamic of these processes through several stages of the "continuum of criminalization". Five types of crimmigration policies and practices of authorities and other actors were identified which produce cumulative effects and reduce space for both political and human action as well as spontaneity.

KEY WORDS: crimmigration, humanitarianism, solidarity, irregular migrants, non-governmental actors

\section{IZVLEČEK}

\section{Kriminalizacija »proimigrantskih« iniciativ: Reduciranje prostora} človeškega delovanja

Članek naslavlja probleme nadzorovanja, discipliniranja in kriminaliziranja nevladnih akterjev, ki v Sloveniji in štirih sosednjih državah pomagajo nedokumentiranim migrantom, prosilcem za azil ali azilantom. Na podlagi izvirnega empiričnega raziskovanja - intervjujev s člani NVO - analizira dinamiko krimigracijskih procesov. Ugotavlja, da kriminalizacija akterjev civilne družbe, ki solidarizirajo z nedobrodošlimi migranti, poteka kot kontinuum petih tipov politik in praks oblasti ter drugih akterjev, ki povzročijo kumulativni učinek in reducirajo prostor tako za politično delovanje kot tudi za človeško spontanost.

KLJUČNE BESEDE: krimigracije, humanitarizem, solidarnost, nedokumentirani migranti, nevladni akterji

PhD in Political Science, Associate Professor, Researcher at the Peace Institute, SI 1000-Ljubljana, Metelkova 6; vlasta.jalusic@mirovni-institut.si 


\section{INTRODUCTION}

The year 2015, when the so-called refugee crisis took place in the EU and the Balkans, brought about the breakdown of European refugee policy (Žagar, Kogovšek Šalamon, Lukšič Hacin 2018), after which increasingly restrictive, militaristic and anti-humanitarian measures were adopted. However, in parallel with the wave of refugees in the "long summer of migration", a wave of solidarity also emerged. Some citizens did not miss the chance to act in genuine human solidarity and to show the potential to counter the "main stream" of crimmigration (Kogovšek Šalamon 2017: 261). Multiple actors were present in solidarity actions and campaigns with refugees, which varied from more traditional humanitarian to ad hoc campaigns, and from local solidarity groups to transnational endeavours (Della Porta 2018: 25; Fekete 2017). While these activities have mostly been "filling the gap" where the states have failed, due to a systematic policy of neglect, they soon became the object of intense "state harassment" (Fekete 2017: 66) and criminalization (Webber 2017).

The criminalization of aid to refugees is not a new phenomenon (Fekete 2017: 2). It was a regular practice in all regimes which were proto- or entirely totalitarian. Luckily, to date, there have always been people who have continued to practice human solidarity, even in dark times and at the price of their own freedom or life. As I have argued elsewhere, one of the main characteristics of proto-totalitarian governments is that they increasingly produce the phenomenon of "double superfluousness" (Jalušič 2017). Not only do they make superfluous those people who are seen as radically unequal and are as such exposed to inhuman treatment (refugees, foreigners, migrants), they also produce the dehumanization and superfluousness of their own citizenry by attempting to destroy their capacities and framework for agency, and hence their spontaneity and politics. In the circumstances of a "normal", democratic political order, humanitarian action is usually not political, as Arendt would claim. Being an expression of compassion, it can easily be perverted into pity (Arendt 1982: 88-90). Nevertheless, such action can become political in extreme conditions when politics as human activity and the space for human action are endangered or on the way to being destroyed.

This thought has led me to rethinking the contemporary criminalization of human solidarity and advocacy work for unwanted, irregular migrants. Of particular interest is the question of why the criminalization of solidarity with migrants, such as advocacy, and even the criminalization of "pure" humanitarian aid, is taking place right now. The article draws upon original empirical research in four countries of "central and south-eastern" Europe conducted in 2017-2018. It adopts the framework of crimmigration studies, which is outlined in the first two sections. The central part of the article presents findings and some conclusions of the analysis of interviews with representatives of ten non-governmental initiatives.

The empirical research was carried out as a part of the project Crimmigration between Human Rights and Surveillance (Peace Institute 2018) which also addressed 
the impact of crimmigration processes on the principles of equality and rights, on human conduct, and on changes to the political and civic culture. We analysed the increasing trends of criminalizing humanitarian aid, while attention was given to practices of assistance and humanitarian interventions for migrants both within and outside of institutions, both formal and informal, in the EU, Slovenia and some countries of the Western Balkans. The main research question was not only what effect does the criminalization of migration have on the equality and rights of individual migrants, but also on general legal principles and on the role of the contemporary state and citizenship rights.

\section{THE CRIMMIGRATION FRAMEWORK}

Crimmigration is most generally understood as the merging of criminal and immigration procedures and the corresponding policies, and the creating of special border regimes and a parallel legal system for the groups of undesirable migrants. The area of criminal law is conflated with that of migration management to the point where they have become "indistinct" (Stumpf 2006; Provera 2015). Provera defines the criminalization of migration as follows:

Criminalisation includes detention, discourse and criminal law measures directed towards irregular migrants as well as identifying penalties which may be grounded in civil law. Criminalisation of migration means the adoption of criminal law characteristics in immigration enforcement and the adoption of immigration consequences for criminal law infractions. (Provera 2015: i)

Four main steps in the process of criminalization of migration can be identified from the crimmigration literature. The first step is discursive creation of migrants as prima facie criminal suspects (Parkin 2016; Guild 2010). The second is the legal definition of those who entered the state without a special permission (visas or even without documents) as "non-persons" or "illegals", who are then subject to consequences of such "criminalization" in secondary law. This happens even if there is no legal basis for criminalization of persons who arrive on the territory without permission in the first place (Provera 2015). In spite of the lack of nexus between increases of the crime rate and intensification of migration, in the third step migrants as a whole are criminalized due to this prima facie predisposition, and the so-called "criminal migrant" (Parkin 2016: 6) is thus constructed. Data show that even when the number of actual migrant crimes decreases, the number of migrants arrested increases (Parkin 2013). Finally, these policies gradually introduce control over the entire population, while at the same time criminalizing and penalizing not only acts of human "smuggling," which is in fact always already a consequence of the definition of "crimes of arrival" (Webber 1996, 2008), but also acts of solidarity, such as basic assistance to migrants, 
housing etc. (Provera 2015). Criminalization of migration clearly separates "foreigners from citizens through an elision of administrative and criminal law language" and it subjects "the foreigner to measures which cannot be applied to citizens, such as detention without charge, trial or conviction". Additionally, the criminalization of persons [...] who engage with foreigners takes place. Individual human contact with foreigners "can be risky as it may result in criminal charges" (Guild 2010: 39).

In addition to severe human rights violations and phenomena of harmful social exclusion, the criminalization of persons who are seeking international protection, racial profiling, border violence, and mass deaths of migrants on the move (see Guild 2010; European Union Agency for Fundamental Rights 2014), there are also other grim consequences of these "trends". State authorities sometimes act contrary to the law - contrary to both international human rights law and also the EU's secondary legislation, such as the European Charter on Human Rights (Provera 2015: 29), whereas the law itself changes its very character (Spena 2013). While initially the development of crimmigration law could have been seen as an "exceptional circumstance", it has become increasingly normalized, and an increasingly acceptable "rule" among the majority of the countries' populations. Exceptions to this include solidarity activities like those emerging along the humanitarian corridor on the Balkan refugee route in 2015 and elsewhere (Fekete 2017; Della Porta 2018), including anti-crimmigration exceptions on the part of the authorities (Kogovšek 2017). But support, protests against crimmigration and assistance to migrants based on the principle of solidarity which established coalitions and succeeded with some demands (Provera 2015; Cantat 2015; Della Porta 2018) soon started becoming contentious and increasingly criminalized (Fekete 2009; Provera 2015; Della Porta 2018; Fekete 2017, Carrera et al. 2018).

In the long term, therefore, criminalization processes affect not only migrants and those who assist them, but also have implications for the present and future framework for action and the rights of the citizens of the states in question. Their "dynamics" change the existing system of government, which is considered to be democratic and respecting of equality, the rule of law, the separation of powers, and universal human rights.

\section{CRIMINALIZATION OF ASSISTANCE TO IRREGULAR MIGRANTS}

Most of the EU literature examining the legal framework of the criminalization of pro-migrant acts of solidarity proceeds from the "Facilitators' Package", which is regarded as the European-wide origin of the criminalization of humanitarian assistance. It consisted of the EU Facilitation Directive, which enables and instructs the Member States to criminalize people who provide various kinds of assistance (transport, food and other necessities such as emergency shelter, etc.) to irregular migrants even without obtaining financial benefit, and does nothing to prohibit the criminalization of such people (see Parkin 2013; Provera 2015; Carrera et al. 2018; 
Fekete 2009, 2017). While the directive allows the possibility of exempting humanitarian assistance from sanction, it leaves the final decision to the Member States (Webber 2017; Carrera et al. 2018: 5). The later Framework Decision demanded the strengthening of penal sanctions by the member states, yet it included a reference to the 1951 Refugee Convention, which excludes punishment for the facilitation of entry for humanitarian assistance (FRA 2014: 9). The result was that in the one half of the EU member states, facilitation of entry is defined as a criminal offence which is punishable by either a prison sentence or a fine, whereas in the other half of the EU this is so even when the "smuggler" does not obtain any financial benefit (see Weber 2017; Carrera et al. 2018: 6).

The implications of criminalizing the facilitation of entry and residence of irregular immigrants, without excepting humanitarian assistance, are grave. This became particularly clear when an open clash emerged between these policies and groups who provide humanitarian assistance, particularly in the cases of the actions of civil society groups carrying out search and rescue operations on the Mediterranean Sea, or in the cases of people who were providing social services and/or legal advice, for example in "hotspots" etc. The search and rescue missions were first directly accused of assisting the smuggler networks and of becoming a "pull factor" for irregular migration, while they refused to cooperate with Frontex to report smuggling and sign the obligatory code of conduct (Carrera et al. 2018: 2-3, 14-18). A study produced for the European Parliament in 2016 clearly problematized the effects of the directive and the "failure to legislate for a clear exemption for humanitarian assistance", which has resulted in a "high degree of legislative ambiguity and legal uncertainty" (Carrera, Guild, Aliverti et al. 2016: 62). Fear, intimidation and harassment by authorities were reported by civil society organizations, in addition to prosecutions and criminal convictions of individuals in some cases. There were court proceedings against people who had helped their family members enter the EU for personal and other altruistic reasons (ibid.: 63) and those who were "just providing food, water and shelter ([...] sleeping bags) became a criminal problem" (Fekete 2017: 2). The criminalization of assistance therefore brought about a general "climate of fear and insecurity regarding irregular immigration". Furthermore, "the 'citizen's right to assist' those in need of humanitarian aid as a key function of democracy" became jeopardized (Carrera, Guild, Aliverti et al. 2016: 63 ff).

A recent study on the criminalization of humanitarian assistance in Europe presents more than 45 cases of prosecution of individuals. All of them were doing pure humanitarian work and were just "filling the gap" in state provision (Fekete, Webber, Edmond Petit 2017). Yet within the framework of criminalization they were "targeted and harassed by the police". Their activities were deemed "anti-social, a 'pull factor' encouraging migration and the nomadic existence at places like Calais and Ventimiglia." Individual humanitarian workers were said to be "enablers of irregular migration" (Fekete 2017: 2). In September 2018, the former Slovenian minister of the interior suggested that a Slovenian legal NGO was facilitating the influx of migrants from 
Croatia and Bosnia and Herzegovina to Slovenia while they were providing migrants with information on their rights and helping them to enter the border procedures that are available to them according to law (Hočevar 2018; Bervar Sternad 2018).

In the context of crimmigration, individuals and organizations that perform acts of humanitarianism became a disturbing problem for the governments, which for years have used a "humanitarian approach" and "humanitarian reason" (Fassin 2012) to govern global crises, wars, genocides, and lately also for border policing (Aas Franko, Gundhus 2015; Garelli, Tazzioli 2018). Backed by facilitation legislation, national governments such as Hungary and recently also Italy have clearly paved the path towards criminalizing humanitarian actions as well by defining a new type of new crime, "crimes of solidarity" (Fekete 2017: 1). Through such legislation the state authorities create hostile environments not only for migrants but also for individuals and organizations that work to counter the securitization of migration, fight for migrants' rights and do not allow themselves to be coordinated into the racist framework (Edmond-Petit 2017; Fekete 2018: 68, 82).

Policies of criminalizing assistance to irregular immigrants "extend beyond cases where civil society actors have faced actual prosecutions and criminal convictions" (Carrera et al. 2018: 1). One of the worrying aspects is the "shrinking political space" for debate and action (Fekete 2017: 2), the narrowing of the legal framework for the agency of non-governmental actors and individuals, as the events in Poland and Hungary have shown (Szuleka 2018).

The concept of "policing the mobility society" was introduced by the latest research on criminalization of solidarity in the EU (Carrera et al. 2018, 2018a) to explain the effects of the punitive dynamics on the civil society actors who are aiding migrants, especially on those who are not providing "pure" humanitarian support like the big humanitarian organizations, and are transcending this framework through critical monitoring and/or political mobilization (Fekete 2017: 2). "Policing the mobility society" describes a "wider set of practices, mechanisms and tools driven by the logic of policing" and affecting both those on the move and those who mobilize and act "on behalf of immigrants and asylum seekers" (Carrera et al. 2018: 3). The term "mobility society" embraces not only traditional NGOs which "play a crucial role in service provision through EU and nationally funded programs and projects", but also informal and loosely organized groups and individual activists (ibid.).

"Policing" stands for more than just traditional surveillance and prevention by police officers or border authorities. It embodies various actions of authorities and of several EU or national institutions that impact (directly or indirectly) the activities of civil society players. Three "faces" or stages of the "policing" actions are described as suspicion/intimidation, disciplining, and criminalization, while inaction and ignorance on the side of authorities was also described as "negative policing" (Carrera et al.: 3-4). The results of the entire study, which are forthcoming (Carrera et al. 2019), reveal broader processes of policing of three sets of civil society actors: search and rescue missions in the Mediterranean, those assisting irregular immigrants and asylum 
seekers in accessing fundamental rights (shelter and food) and those advocating for their rights.

The conceptual framework of "policing" with three faces/phases is in many ways similar to what we have outlined in our project as several phases in the "continuum of criminalization", although our findings pointed to more than just three instances/ types of criminalization. Besides, "policing" can also be carried out by other non-governmental actors, especially the far right.

\section{METHODOLOGY}

In addition to an analysis of previous research and data on the criminalization of humanitarian assistance, we prepared a semi-structured qualitative questionnaire for representatives of NGOs offering humanitarian or other assistance to migrants that are active in Slovenia and neighbouring countries. The aim was to find out which organizations are being targeted by the criminalization trends, what kind of surveillance and punishment is used by authorities and other actors and how does this affect NGOs and citizens. The questionnaire consisted of five sets of questions, including those about the type of work and organization and whether they offer humanitarian and/or other kinds of assistance. Questions were asked to assess trends in migration policies in their countries and the EU and to describe the observed criminalization or other problematic practices of authorities toward irregular migrants and refugees.

Ten anonymous qualitative interviews were carried out from November 2017 to May 2018 with members, employees and volunteers of various civil society associations (NGOs) or more loosely organized groups from Slovenia (5) and four neighbouring countries: Croatia (1) Austria (1), Hungary (2) and Italy (1). All or part of their work is dedicated to refugees, asylum seekers and irregular migrants, and can be considered as solidarity work (either humanitarian or broader). ${ }^{1}$ The main objective was to obtain a deeper insight (through the lens of the actors) into some of the most typical practices of policing and criminalization of both migrants and those who provide them with different types of assistance.

In the last part of the interviews the respondents were invited to talk about their organizations' relationships with the authorities and about any cases of harassment, "policing" and criminalization of their or others actors' work: had they ever been discredited, publicly criticized or defamed, had their work been obstructed, ignored, or indirectly or directly criminalized, and how did that happen, had they

1 Provera defines solidarity in a narrower sense as "providing, or assisting migrants to access, basic rights such as health care, accommodation, education, transport as well as necessities such as food and clothing" and ethically as "behaviour which might be considered humanitarian - that is, the individual or entity might consider their act to be "good" yet is otherwise subject to sanction" (Provera 2015: 5). 
been prosecuted, interrogated or otherwise charged, and had any of their or other actors' activities or forms of assistance been prohibited by law or criminalized. The rest of the article focuses on the results and analysis of the last set of questions.

\section{FINDINGS}

All of the respondents had an intense experience with the so called "long summer of migration" in 2015-2016 and with the subsequent developments both in their countries and in the EU. During the crisis they engaged in border monitoring, providing information, and also humanitarian aid, including collecting and donating clothing, cooking and providing refugees with fresh food. Only two of the respondents see their organizations as mainly "humanitarian" and this should be understood in a broader sense as they also provide information, conduct monitoring, and provide advocacy, legal advice, basic rights counselling, etc. Others describe their work strictly as advocacy and legal representation, free legal help, monitoring, information provision, informing clients about procedures, representing them, etc. All of the organizations generate knowledge, and produce studies, monitoring and research reports.

\section{Migration Policies in the EU and in Member States}

The respondents are highly critical of the EU's policies and their governments' measures, and assess them as "very, very restrictive", "unwelcoming" (Slovenia), "aggravating and rigid", resembling a "Fortress Europe" approach (Croatia), and "really bad" (Hungary). Hungary in particular is identified as the leader in enforcing restrictive policies, by preventing arrivals and criminalizing and punishing irregular migrants, including asylum seekers. Moreover, it incresingly criminalizes organizations helping migrants:

I don't know if it can get lower than it already went. For several years, migration has been one of the main topics misused by the politicians to gain power, [and] the media report selectively, [and it] also produces disinformation. Non-governmental organizations are under serious preassure. If the Stop Soros laws ${ }^{2}$ are adopted we won't be able to operate any more. (Interview 7; 4. 5. 2018)

2015/2016 marked a total breakdown of the EU's migration policy, which could be interpreted as a "temporary win, [i.e.] success of migration". After that, "the backlash of the EU border regime" took place and "the empire struck back" (Interview 6; 15. 3. 2018). There is a close interrelation between restrictive Member State policies and

2 Regarding the Stop Soros laws see Kingsley 2018. 
the direction received from the EU. The Hungarian "solution", the respondents said, is widely tolerated only because the EU migration policy collapsed, and it is on this basis that the Hungarian government can afford "to do what they are doing" ("building fences, pushing people back, torturing them, beating them" (ibid.). Not only do "many countries in fact support Orban's policy of banning migrants from the Balkans" (Interview 7; 4. 5. 2018), it is also "in the EU's interest to keep the corridor closed, and the Hungarian fence is an important element" of that (Interview 6; 15. 3. 2018).

This became more obvious when tackling the specific problematic practices affecting migrants, and the unconstitutional conduct of the responsible authorities, which violate the European Convention on Human Rights and international law documents, or as one respondent said, they violate "everything" (Interview 7; 4. 5. 2018). The "trend" which is moving further towards violence was unambiguously described as follows:

[...] Croatian and Hungarian police forces in particular are not only pushing people back to Serbia on a regular basis [...] with mass violence, regularly crossing the line of torture. All of this is well documented. But at the moment [...] nobody really cares. [...] I haven't heard any criticism from Brussels regarding the mass violence that is happening. [...] These stories [...] are very systematic [...], so anybody who looks into it more clearly knows what's going on nowadays. It's violently protecting the border. It all just shows that the fence is not enough. It was the same with the Berlin Wall. Think about the Berlin Wall without people to shoot. It would be absolutely useless [...] I mean now we have a situation of immediate push-backs and this is connected to mass violence, so what else are they going to do? The next logical step is really to order them to shoot. (Interview 6; 15. 3. 2018)

Some respondents, not only Hungarian ones, whose organizations cooperate with authorities, noticed the deterioration of this relationship after 2015/2016. This process went hand in hand with increased public attacks on them and with the attempts of the EU and Member states to limit the autonomous work of NGOs and individuals offering assistance. While it seemed that the most extreme of such developments took place in Hungary, other countries are no longer exceptions.

\section{Types of Restrictions, Obstruction and Criminalization}

We identified five types of practices and approaches aimed at obstructing or precluding the work and activities of non-governmental organizations, and thus narrowing their space of agency.

a) Criticism and public attacks, discrediting of the work of NGOs in the media, disinformation, and harassment by right-wing politicians and their allies. "It was said that 
we are importing migrants to Slovenia, work for them and take care for the migrants' better lives instead of Slovenians', and that we should take these migrants into our homes" (Interview 1; 4. 12. 2017). While these intimidations are not new, respondents the were criticized and exposed to harassment mostly by right-wing actors, and not mainly by the authorities, except in the Hungarian and Croatian cases. Direct attacks on NGOs, in Slovenia for example, were carried out by newspapers and one news portal connected to a right-wing party which is openly aligned with the Hungarian prime minister Orban. Organizations and individuals received threats via social media. Both in Slovenia and Croatia these attacks were aimed not solely at activities of solidarity with migrants but also at their work and civil society in general. There were numerous intersections between gender and migration. One Croatian NGO was publicly criticized by the authorities in a patronizing manner, even being accused of being anti-Croatian.

The attacks discredit the work of NGOs as incompetent, useless, dangerous and anti-state, and comment on the financial resources of these allegedly "rich" and corrupt organizations, while the reports are not fact-based. A clear ideological pattern exists behind such accusations, in which they match a "suitable" enemy (Fekete 2009) with a conspiracy theory. The Austrian respondent stated that many volunteers dealt with intimidation and hate speech, yet these did not come from officials.

Hungary faced the most powerful propaganda, where coordinated attacks by the media, right wing parties and the government stoked sentiments against NGOs that deal with migration or are financed by George Soros. Most media continually portrayed them as acting in opposition to the state interest, and dangerous to society; Soros's agents and soldiers, who are jeopardizing Christian values and the safety of Hungarian citizens, want to fill Hungary with Muslims, and are connected to terrorists. The government even carried out open defamation of the NGOs under the cover of a quasi-deliberative democracy while sending citizens surveys with questions like "do you support organizations like the Hungarian Helsinki Committee and Amnesty International which are assisting terrorists".

Respondents whose organizations were rarely or not criticized (2) thought that this was due to the nature of their work. They are "in a more favourable position" because their work is "primarily humanitarian and not advocacy-oriented" (Interview $2 ; 7$. 12. 2017). Or they are not at the centre of the pressure because the knowledge/ information their small organization collects is intended largely for NGOs and professionals (Interview 6; 15. 3. 2018).

Slovenian and Croatian NGOs were targeted by demands that the governments cease all state funding of the NGOs, particularly those organizations which were or are financed by OSIFE. In Hungary, the government proposed taxing these organizations up to $25 \%$.

b) Bureaucratic tightening of the space for civic action: restricting access, obstructing of work and surveillance. The NGOs needed to be quite disciplined in their relationship 
with the officials in order to get access to information or to be allowed to work at the border with migrants or in detention centres or transit zones. Respondents recall many instances where the authorities restricted or banned access to borders or detention centres for activists, volunteers and various NGOs. They were often ignored, directly obstructed or punished for their endeavours, especially when they for example entered the border area.

Obligatory registration with the large humanitarian organizations such as the Red Cross, Caritas or UNHCR, and restriction of access for those who assisted refugees were the first steps of disciplining the work of NGOs in 2015/2016, at the time of the European refugee "crisis". A Slovenian NGO faced restrictions from the Ministry of the Interior to access the parts of the refugee centres where the registration took place after they publicly criticized the observed violations of the Convention. The justification suggested that the NGOs were "not constructive enough". The Ministry of the Interior apparently had very good information about which organizations had been critical.

I think that the authorities succeeded very quickly [...] in pushing out all of the informal groups from the refugee centres with the argument that they only create chaos, but they basically wanted total surveillance of all forms of humanitarian aid. And that was how humanitarian work was performed later: in an automatic manner, very technical. So, if you are distributing food or clothes or you carry a box then that was humanitarian work, yet talking to the people, providing them with information, that was not humanitarian work anymore. And talking to people, and providing them with information, was the most unwelcome. (Interview 1; 4. 12. 2017)

However, it was not only about what kind of assistance was given (information and advocacy were not welcome) but also about who was offering it:

[...] the volunteer kitchen was kicked out as well, and the argument was that the military kitchen would provide people with hot food, which in the end didn't happen [...]. It was just [...] to get the volunteer kitchen out. Our spaces for volunteers were continuously being reduced, and [...] there was a certain scheme behind this. [...] there was one scheme stopping the flow of people and another scheme stopping the access of volunteers. (Interview 5; 9. 3. 2018)

All "unauthorized" aid was considered increasingly problematic. The authorities would not necessarily obstruct the NGOs' work directly, but by not providing information, "or they put additional demands on us to provide non-essential information when it came to advocacy for asylum, for example. That way they made it harder for us to reach any constructive solutions" (Interview 2; 12. 12. 2018). 
c) Banning access and prohibiting monitoring. In Hungary, the most important human rights NGO had their 15-year-old contract with the immigration office and the police cancelled, including a tripartite agreement on border monitoring with UNHCR. For years, they had direct access to any centre in which asylum seekers were located.

All of this ceased in 2017, in the spring, without any explanation or with very illogical reasons: for example, that such monitoring was not needed as there is an ombudsman and a'national preventive monitoring mechanism', and they are going to these places [...]. Every three years they go to a certain centre, [...], so it's a completely different way of monitoring. The cancellation was purely political. (Interview 7; 5. 5. 2018)

The authorities also attempted to prevent their lawyers from accessing the transit zones, which luckily failed after a petition by the Hungarian Bar Association.

The arguments were nonsensical. The migration office wrote that in 15 years we missed the deadline to send the report on these monitoring visits three times by couple of days, I think, [and] then that our lawyer behaved badly in court in one case [...]. It was a clear decision by the government to ban us from access. (Interview 7; 5. 5. 2018)

There were only few organizations left that were granted access to the transit zones by the state, all of them strictly humanitarian, and most of them religious organizations, i.e. the so-called Charity Council (consisting of Caritas, the Maltese Order, Interchurch Aid, the Red Cross, Reformed Church, Baptist Aid). "There is no exact information about what activities each of these organizations perform there. If they have access, they do not have the permission to report anything about the situation in the transit zones to the public [...], everything is actually secret" (Interview 7; 5. 5. 2018).

d) Deterrence and marking of "dangerous" organizations and persons. Before the elections in 2018, the Hungarian government informed the public that they had a list of about 200 people who are closely connected with George Soros and his network and therefore act contrary to the state's interests. After the elections, the magazine Figyelo Review, which is majority-owned by the state, published a list of "suspicious" people in an article that ran under a pseudonym:

They copied names from the various websites of the organizations that were considered a threat to the country, as well as the names of many CEU professors, many CEU associates and many civil society organizations - entire lists of people working in NGOs; about 200 names were published. (Interview 7; 4. 5. 2018)

While the lists of "corrupt" and "traitorous NGOs" or "murderous abortionist lobbies" are also constantly republished by certain media in Slovenia, the Croatian respondent 
indicated that they suspect that they are under surveillance by various intelligence organizations, and that there is a political agenda of several institutions in Croatia to discredit their work. "That's why there aren't many people who would publicly expose themselves as working with migrants, since this has become a certain stigma, stretching from treason to Islamization and beyond" (Interview 4; 2. 2. 2018).

Yet most of the respondents did not mention particular situations in which their work was directly criminalized, although they had heard of or witnessed problems in the relationships between the official bodies and the organizations whose work and efforts were directly or indirectly accused of being criminal, or denounced by the institutions, for example in Sicily (Interview 9; 5. 2. 2018).

In Slovenia in 2015, informal volunteer organizations which did not register with the big humanitarian organizations like the Red Cross or Caritas etc. were often punished for their actions, for example in the space between borders, in no man's land:

It was said that no one is allowed to offer aid there and at the beginning some people who were purely self-organized received fines for misdemeanours. So this was criminalized and after that no one in the public supported such actions any more. This was how activism was marked as an ugly rebellion against the system and made suspect. (Interview 1; 4. 12. 2017)

There is a belief that the work of the NGOs will be further interrogated and discredited by the authorities. The Croatian respondent expects the Hungarian scenario to spread:

During our practice of escorting refugees to the police stations [...], some of the police officers expressed anger and even made threats (such as accusing us of smuggling people and that we could potentially expect to be charged). Innumerable times [...] our colleagues would be exposed to denigration and assaults by high state officials in closed rooms. [...] The Ministry of the Interior would organize the meeting with us and the NGOs providing humanitarian assistance where they would brag about their successes and the humanitarian face of their work. (Interview $8 ; 12.3 .2018$ )

e) Direct criminalization of assistance. During the fieldwork early in 2018, the respondents often referred to the draft Hungarian anti-immigration law which would directly criminalize the provision of any kind of assistance to migrants, including basic help for migrants and asylum seekers:

The law requires licenses and if an organization performed activities without a licence, it would be a violation of the law, your tax number would be frozen, [...] the organization would be banned. In the third part of the law there is a prohibition against people coming within eight kilometres of the border between Hungary and Serbia. (Interview 7; May 2018) 
The targeted organizations were those that are very active in supporting asylum seekers or refugees, in particular human rights defenders: "The law is really made in order to get rid of us [...] as we are the strongest organization which criticizes the acts of the state in the field of human rights" (Interview 7; 4. 5. 2018).

\section{DISCUSSION AND CONCLUSIONS: THE CRIMMIGRATION CONTINUUM AND THE SHRINKING SPACE OF POLITICS}

The five main types of "policing" that we came across in the interviews can be described as a continuum ${ }^{3}$ of the criminalization of the organized and independent provision of assistance to ("irregular") migrants. The continuum begins with discursive criminalization, involving intimidation and suspicion, as described by Carrera et al. (2018). The process is accompanied by public incrimination of non-governmental activities through political and media discourses and "semantic drifts" which link them to criminals and smugglers, and accuse them of being "pull factors" and "national traitors" (Fekete 2018: 67). This includes disinformation, non-factual incrimination of allegedly rich and corrupt NGOs, and accusations of being traitors and allies of terrorists who are becoming a part of the bigger picture of the enemy (Fekete 2009), which fits well into the simple explanations of conspiracy theories. Our respondents have confirmed that alt-right topics are feeding this "news" (see Fekete 2017a: 33). The harassment can also go beyond disturbance (Fekete 2017a: 33, Carrera et al. 2018: 27), though our respondents luckily did not have experiences with physical attacks.

The second type of policing is characterized by the bureaucratic tightening of the space for civic action. Organizations and volunteers are required to register, to cooperate, and accept the practices of "knowledge extraction", such as sharing information and duty to report (Garelli, Tazzioli 2018: 679) that are carried out by participants in the "military-humanitarian war against migrant smugglers" (ibid.). If they fail to do so, their activities might be restricted. Suspicion is directed at those who are not ready to "go with the flow", especially more informal organizations which do more than just ensuring survival. A difference emerges between two kinds of "humanitarianism": a less formal, more spontaneous and direct type, allowing contact and communication between people, and the strictly organized routine of big organizations which provide for basic needs only. Informal, spontaneous groups are pushed out of the game. The only participants that are welcomed are those that do not engage in advocacy and will not talk much to the people, and will not monitor or report the authority's actions or misconduct.

3 "Continuum of crimmigration" refers to the concept of "continuum of (sexual) violence" (Kelly 1987) which is suggesting that women experience a whole series of violations of their sexual integrity which were not contained within legal parameters that defined sexual offences before they experience brutal sexual violence. 
The next step is banning access and the possibility of monitoring. The Hungarian case has shown that only selected humanitarian organizations get access to migrants. This confirms Fassin's argument, in his critique of humanitarian reason (Fassin 2011), about the governing of the unwanted. The radical inequality which forms the core of the humanitarian aid discourse is always already implicated in the system of governance, which first silences the language of rights and injustices and then resorts to pity instead of genuine human solidarity. As confirmed in practice, finally even pity, which would give scant alms, is abolished.

While the fifth stage involves the introduction of substantial restrictions, both administrative and penal, and attempts to justify the whole process of penalization and surveillance by legal means, the fourth stage is even more problematic. Lists of suspects create the living targets of governmental and nongovernmental attacks. Direct criminalization through legislation is mainly a consequence of previous steps which prepare the ground for it.

The notion of the "shrinking space of civil society" (Szuleka 2018) points to the developments in the last few decades, in which the governments have been continuously placing increased restrictions on non-governmental actors through policies or legal amendments which primarily affect those who are critical of the state's policies (ibid.: 11). While the authorities create an unwelcoming political culture and try to prevent all elements of spontaneous migration (see Weber in Fekete 2018: 67), there is also clear evidence not only of shrinking political space but of attempts at destroying any spontaneity, one of the most important elements of human action. Aid not only gets regulated, those initiatives which are contrary to the "humanitarian missions" of those who are fighting smugglers and quasi-defending the social rights standard and sovereignty of the "West" are by definition suspect.

In late August 2018, reports were coming from Hungary that the authorities had cut off the distribution of food to some rejected asylum seekers in the transit zones. The parliament adopted legislation which is supposed to justify such measures, and criminalizes humanitarian activities for migrants, making them punishable by up to a year in prison. In Italy as well, a hostile environment is created to prevent both spontaneous migrations and any spontaneous initiative to offer aid or solidarize. News comes in from the Mediterranean on a daily basis about search and rescue ships that are not allowed to enter the ports for weeks. "Policing humanitarian borderlands" (Aas Franko, Gundhus 2015) has become increasingly anti-human. Yet, as indicated at the beginning, this policing is anti-human in a double way, as it not only affects

4 On 20 November 2018 the Mediterranean rescue ship Aquarius was seized by the Italian authorities, and Doctors Without Borders (MSF), one of the two humanitarian organizations operating on board the ship, was accused of "improperly disposing of the waste accumulated during its activities at sea". MSF rejected the accusations of illegal practices and said that the seizure represented "another strike in the series of attacks criminalizing humanitarian aid at sea" (Aquarius Rescue Ship Seized 2018). 
the lives and therefore the agency potential of migrants, but increasingly also the space and political potentials of the "peoples of Europe".

The criminalizing of practices of solidarity across the whole of Europe indicates that the authorities are trying to limit the autonomous work of organizations by taking over the majority of activities connected with migrants, trying to discredit their work by publicly demonizing them and potentially criminalizing them. Such demonization of people working with migrants is, as our respondent said, "much more effective than direct criminalization, since it leads people to giving up or hiding their activities". And this is the ultimate path to dehumanization.

\section{REFERENCES}

Aas Franko, Katja, Gundhus, Helene (2015). Policing Humanitarian Borderlands: Frontex, Human Rights and the Precariousness of Life. British J. of Criminology 55, 1-18. Aquarius Rescue Ship Seized: NGO Accused of Dumping Dangerous Waste at Italian Ports (2018), https://www.thelocal.it/20181120/aquarius-rescue-ship-msf-ngo-dumping-hazardous-waste-at-italian-ports (20. 11. 2018).

Arendt, Hannah (1982). On Revolution. Harmondsworth, Middlesex: Penguin Books-Pelican Books.

Bervar Sternad, Katarina (2018). Nevladna organizacija PIC varuje temeljne pravice ljudi v Republiki Sloveniji. Delo, 12. september 2018, https://www.delo.si/novice/ slovenija/nevladna-organizacija-pic-varuje-temeljne-pravice-ljudi-v-republiki-sloveniji-90592.html (19. 11. 2018).

Cantat, Celine (2015). Contesting Europeanism: Discourses and Practices of Pro-migrant Organisations in the European Union. PhD thesis, University of East London, https://popups.uliege.be/2295-0311/index.php?id=138 (20. 8. 2018).

Carrera, Sergio, Allsopp, Jeniffer, Vosyliute, Lina (2018). The Effects of Anti-Migrant Smuggling Policies on Humanitarian Assistance in the EU. International Journal of Migration and Border Studies (IJBMS) - Special Issue, forthcoming, https://gtr. ukri.org/publication/overview?outcomeid=5aa85eece3ddc5.75737244\&projectref=ES/P001335/1 (15. 7. 2018).

Carrera, Sergio, Allsopp, Jeniffer, Vosyliute, Lina (2018a). Main Research Findings of ESRC Project on The Effects of EU's Anti-Smuggling Policies on Civil Society Actors, http://www.picum.org/Documents/Publi/2018/Main-Findings-of-the-Report-2018.pdf (9. 8. 2018).

Carrera, Sergio, Guild, Elspeth, Aliverti, Anna, Allsopp, Jeniffer, Manieri, Giovanna, Levoy, Michele (2016). Fit for Purpose? The Facilitation Directive and the Criminalisation of Humanitarian Assistance to Irregular Migrants. Brussels: LIBE, http://www.europarl.europa.eu/RegData/etudes/STUD/2016/536490/IPOL_STU(2016)536490_ EN.pdf (21. 8. 2018). 
Della Porta, Donatella (2018). Contentious Moves: Solidarity Mobilizations in the 'Long Summer of Migration'. London: Palgrave Macmillan.

Edmond Petit, Anya (2017). The 'hostile environment' - the lived experience in Calais. Humanitarianism: The Unacceptable Face of Solidarity (eds. Liz Fekete, Frances Webber, Anya Pettitt Edmond). London: Institute for Race Relations, 22-27.

Fassin, Didier (2011). Humanitarian Reason: A Moral History of the Present. Berkeley: University of California Press.

Fekete, Liz (2009). A Suitable Enemy: Racism, Migration and Islamophobia in Europe. London: Pluto Press.

Fekete, Liz (2017). Introduction. Humanitarianism: The Unacceptable Face of Solidarity (eds. Liz Fekete, Frances Webber, Anya Pettitt Edmond). London: Institute for Race Relations, 1-6.

Fekete, Liz, (2017a). "Traitors of the Nation!" Humanitarianism: The Unacceptable Face of Solidarity (eds. Liz Fekete, Frances Webber, Anya Pettitt Edmond). London: Institute for Race Relations, 31-37.

Fekete, Liz (2018). Migrants, Borders, and the Criminalisation of Solidarity in the EU. Race \& Class 59/4, 65-83.

Fekete, Liz, Webber, Frances, Pettitt Edmond Anya (2017). Humanitarianism: The Unacceptable Face of Solidarity. London: Institute for Race Relations.

Garelli, Glenda, Tazzioli, Martina (2018). The Humanitarin War Against Migrant Smugglers at Sea. Antipode 50/3, 685-703.

Guild, Elspeth (2010). Criminalisation of Migration in Europe: Human Rights Implications. Council of Europe: Commissioner for Human Rights, February 2010, http:// www.refworld.org/docid/4b6a9fef2.html (20. 8. 2018).

Hočevar, Barbara (2018). Ministrica obtožuje nevladnike: Ravnajo sporno, saj poskušajo vplivati na postopek ravnanja s tujci (Minister Accuses Non-Governmetals: They Act in an Contentious Way as they Attempt to Influence the Procedure of Treating the Foreigners), Delo, 8. september 2018, https://www.delo.si/novice/slovenija/nevladniki-so-prestopili-mejo-89685.html (19. 11. 2018).

Jalušič, Vlasta (2017). Refugees Today: Superflousness and Humanitarianism. Estudos Ibero Americanos 43/3, 524-534, http://revistaseletronicas.pucrs.br/ojs/index. php/iberoamericana/article/view/26139 (21. 7. 2018).

Kelly, Liz (1987). The Continuum of Sexual Violence. Women, Violence and Social Control: Explorations in Sociology (eds. J. Hanmar, M. Maynard). London: Palgrave Macmillan, 44-60.

Kingsley, Patrick (2018). Hungary Criminalizes Aiding Illegal Immigrants, https://www. nytimes.com/2018/06/20/world/europe/hungary-stop-soros-law.html (7. 8. 2018). Kogovšek Šalamon, Neža (2017). Mass Migration, Crimmigration and Defiance: The Case of the Humanitarian Corridor. Southeastern Europe 41, 251-275.

Parkin, Joanna (2013). The Criminalisation of Migration in Europe: A State-of-the-Art of the Academic Literature and Research, CEPS Papers in Liberty and Security in 
Europe No. 61, https://www.ceps.eu/system/files/Criminalisation\%20of\%20Migration\%20in\%20Europe\%20J\%20Parkin\%20FIDUCIA\%20final.pdf (13. 5. 2018).

Peace Institute (2018). Crimmigration Between Human Rights and Surveillance, http://www.mirovni-institut.si/en/projects/crimmigration-between-humanrights-and-surveillance/ (19. 11. 2018).

Provera, Marc (2015). The Criminalisation of Irregular Migration in the European Union. CEPS Paper in Liberty and Security in Europe 80, https://www.ceps.eu/system/ files/Criminalisation\%20of\%20Irregular\%20Migration.pdf (13. 7. 2017).

Spena, Alessandro (2014). Iniuria Migrandi: Criminalization of Immigrants and the Basic Principles of the Criminal Law. Criminal Law and Philosophy 8/3, 635-665.

Stumpf, Judith (2006). The Crimmigration Crisis: Immigrants, Crime and Sovereign Power. American University Law Review 56/2, 367-420.

Szuleka, Małgorzata (2018). First Victims or Last Guardians? The Consequences of Rule of Law Backsliding for NGOs: Case studies of Hungary and Poland, CEPS Papers in Liberty and Security in Europe 6, https://www.ceps.eu/system/files/MSzuleka_ RoLandNGOs.pdf (15. 7. 2018).

Webber, Frances (1996). Crimes of Arrival: Immigrants and Asylum-Seekers in the new Europe. London: Statwatch, http://www.statewatch.org/analyses/crimes-of-arrival.pdf (17. 7. 2018).

Webber, Frances (2008). Border Wars and Asylum Crimes. London: Statewatch.

Webber, Frances (2017). The Legal Framework: When Law and Morality Collide. Humanitarianism: The Unacceptable Face of Solidarity (eds. Liz Fekete, Frances Webber, Anya Pettitt Edmond). London: Institute for Race Relations, 7-21.

Žagar Ž., Igor, Kogovšek Šalamon, Neža, Lukšič Hacin, Marina (eds.) (2018). The Disaster of European Refugee Policy: Perspectives from the Balkan Route. Cambridge: Cambridge Scholars Publishing. 


\section{POVZETEK}

\section{KRIMINALIZACIJA "PRO-IMIGRANTSKIH" INICIATIV: REDUCIRANJE PROSTORA ČLOVEŠKEGA DELOVANJA Vlasta JALUŠıČ}

Članek naslavlja probleme nadzorovanja, discipliniranja in kriminaliziranja nevladnih akterjev, ki v Sloveniji in štirih sosednjih državah, Avstriji, Madžarski, Hrvaški in Italiji, pomagajo nedokumentiran migrantom, prosilcem za azil ali azilantom. Izhaja iz konceptualnega okvira krimigracij, ki analizira učinke povezovanja in zlitja kazenskega prava in upravljanja migracij. Posledice niso samo kršitve človekovih pravic in izključevanje, kriminalizacija prosilcev za mednarodno zaščito, rasno profiliranje, nasilje na mejah ter množično umiranje migrantov na poti, ampak tudi nadzor in kriminalizacija tistih, ki z njimi solidarizirajo in jim nudijo osnovno humanitarno pomoč, kar kaže na proces »dvojne dehumanizacije«.

EU od leta 2002 zapoveduje penalizacijo pomoči nedokumentiranim migrantom, ne da bi eksplicitno izključevala humanitarno pomoč. V številih državah EU se je - še zlasti po letu 2015 - močno povečalo kazensko sankcioniranje tistih, ki ne nudijo samo zagovorništva in informacij, ampak tudi humanitarno pomoč v najelementarnejšem pomenu. Nevladne iniciative so, ker naj bi spodbujale nezakonite migracije, obdolžene spodkopavanja interesov in varnosti evropskih držav. Nekatere desne vlade ožijo tudi zakonite podlage za delovanje civilne družbe.

$Z$ namenom globljega vpogleda $v$ dinamiko in posledice krimigracijskih procesov na področju pomoči migrantom je avtorica skupaj s študentko Arijano Radić med novembrom 2017 in majem 2018 izvedla deset kvalitativnih intervjujev s člani različnih nevladnih organizacij ali bolj neformalno organiziranih iniciativ. Ugotovila je, da nadzorovanje in kaznovanje akterjev nevladnih iniciativ, ki poteka kot »krimigracijski kontinuum «, obsega pet tipov praks in politik: diskurzivno kriminalizacijo, birokratsko oženje prostora za državljansko delovanje, prepoved dostopa in možnosti za monitoring, zastraševanje in označevanje »nevarnih« organizacij in oseb ter neposredne spremembe administrativnih in kazenskih predpisov. Kumulativni učinki omenjenih politik in praks reducirajo prostor političnega, človeškega in humanitarnega delovanja ter spontanosti. 